\title{
UNIDADES DE PAISAGEM NO BAIRRO SANTA FELICIDADE, CURITIBA-PR: CONTRIBUIÇÃO PARA UMA CARTOGRAFIA DE SÍNTESE
}

\author{
LANDSCAPE UNITS IN THE BOROUGH OF SANTA FELICIDADE, CURITIBA-PR: SUBSIDIES FOR A SYNTHESIS \\ CARTOGRAPHY
}

\section{RESUMO}

Considerando os estudos da paisagem sob a perspectiva geossistêmica, o trabalho teve como objetivo a delimitação de unidades de paisagem e suas aplicações no planejamento do bairro Santa Felicidade (Curitiba-PR). Reuniram-se dados cartografados do meio físico-biológico e antrópico, oriundos de pesquisas desenvolvidas no bairro e que foram organizados em um Sistema de Informações Geográficas, para auxiliar no processo de síntese. Foram delimitadas unidades de paisagem originais, pretéritas à intensa ocupação do bairro e, com a inserção dos dados da ocupação antrópica atual encontraram-se quatro unidades de paisagem. $\mathrm{O}$ bairro apresenta grande diversidade de paisagens, porém com a tendência a homogeneização por meio do adensamento populacional e de edificações. A técnica de delimitação de unidades de paisagens proporcionou uma visão aplicada, constituindo em uma ferramenta útil para a cartografia de síntese e ao planejamento da paisagem. As características de cada unidade de paisagem permitiram a proposição de ações de planejamento, tais como programas de educação ambiental, restrições de uso e ocupação com base na legislação, criação de espaços livres de edificação, entre outras intervenções.

Palavras-chave: Geossistema, Geografia de Síntese, Geoecologia Urbana, Cartografia Temática, Planejamento da Paisagem.

\section{ABSTRACT}

Looking at landscape studies under the geosystemic perspective, this work has as its objective the definition of the landscape units boundaries, and their applications, in the Santa Felicidade Borough (Curitiba-PR) zoning. We gathered cartography data from the physical-biological and anthropic environments, originated from the research done in the borough which were organized in a Geographic Information System to help the synthesis process. We established the original boundaries, prior to the intense occupation of the borough and, after entering the current anthropic occupation, we found four landscape units. The borough features a large diversity of landscapes, but is showing a tendency to homogenization, due to population density increase and buildings. The creation of landscape units boundaries technique offered an applied vision, becoming an useful tool for synthesis cartography and landscape planning. The features of each one of the landscape units allowed for the planning actions proposal, such as environmental education programs, usage restrictions and legislation based occupation, the establishment of building free areas, among other interventions.

Keywords: Geosystem, Synthesis Geography, Urban Geoecology, Theme Cartography, Landscape Planning.

\author{
Anderson Luiz Godinho Belem ${ }^{\text {a }}$ \\ João Carlos Nucci ${ }^{b}$ \\ a Instituto Federal Farroupilha (IFFar), \\ São Borja, RS, Brasil \\ b Universidade Federal do Paraná (UFPR), \\ Curitiba, PR, Brasil
}

DOI: $10.12957 /$ geouerj.2020.28982

Correpondência: andebelem@gmail.com

Recebido em: 1 jun. 2017

Revisado em: 6 abr. 2019 Aceito em: 8 fev.2020 


\section{INTRODUÇÃO}

A perspectiva da integração entre os elementos bióticos e abióticos pertinentes ao conceito de Paisagem surge logo na conformação da Geografia como disciplina científica por meio da obra de Humboldt, que em suas pesquisas identificou, por exemplo, estruturas geobotânicas da superfície da Terra. Mais tarde com o advento da teoria sistêmica, as discussões sobre a Paisagem e suas unidades espaciais aparecem em diferentes escolas da geografia, muitas vezes isoladas umas das outras como o caso da soviética e da francesa.

$\mathrm{Na}$ atualidade, com o uso da tecnologia, o ser humano é capaz de realizar medições mais precisas dos diferentes elementos que compõem a paisagem como o solo, a água, a vegetação, os usos da terra, dentre outros, porém a noção do todo muitas vezes se perde. Assim, os estudos que visam identificar unidades de paisagem se tornam relevantes, pois atentam justamente para o resultado da integração dinâmica dos elementos e não para os elementos individualmente, sendo esse procedimento útil ao planejamento da paisagem seja em meio urbano ou rural.

O Planejamento da Paisagem se insere nesse contexto, por se tratar de uma ferramenta importante e relevante, cuja concepção inicial ocorre no século XIX na Alemanha, vinculado mais com as questões estéticas e de embelezamento da paisagem, porém, com o avanço da sociedade urbano/industrial e as novas necessidades de ordenamento do uso do solo, em função da manutenção da qualidade ambiental e da conservação da natureza, suas diretrizes foram reformuladas. Atualmente, o Planejamento da Paisagem se configura como uma importante proposta, institucional em alguns países, para diminuir a pressão sobre a natureza, mantendo assim suas funções ecológicas como qualidade dos solos, dos recursos hídricos, conservação da fauna e flora (WILKE, et al., 2002; HAAREN, et al., 2008).

No âmbito do projeto "Planejamento da Paisagem como subsídio para a participação popular no desenvolvimento urbano", desenvolvido pelo grupo de pesquisa "Planejamento da Paisagem" (DGEOG-UFPRCNPq), diversos trabalhos acadêmicos levantaram dados buscando compreender a potencialidade dos elementos das paisagens, ou seja, seus limites e aptidões, bem como a demanda da sociedade (desejos e necessidades) no bairro de Santa Felicidade (Curitiba-PR). Os levantamentos desenvolvidos tiveram um caráter operativo (dados voltados ao planejamento) e espacializado (expressão cartográfica), visando, posteriormente, uma visão integradora (análise sistêmica), por meio da delimitação de unidades de paisagem e sua caracterização (NUCCl, 2010).

Deste modo, a pesquisa objetiva, com base nos dados gerados pelo grupo de pesquisa "Planejamento da Paisagem", disponível em Nucci (2010), apresentar uma proposta de delimitação de unidades de paisagem, de acordo com uma cartografia de síntese, além de um quadro de correlações entre as Unidades de Paisagem 
e seus elementos constituintes, possibilitando uma análise sistêmica do bairro de Santa Felicidade, no município de Curitiba-PR.

\section{REVISÃO BIBLIOGRÁFICA}

No estabelecimento da Geografia como ciência Alexander von Humboldt fazia em seus estudos sínteses parciais. Utilizava-se da linguagem científica moderna e atrelava a explicação do conjunto orgânico ou da totalidade por meio de descrições detalhadas e representações não apenas escritas. Abrahão (2009, p. 223) comenta que "o esforço de síntese realizado pelos cientistas românticos se aproxima da abordagem ecológica contemporânea".

Com o paradigma positivista, a tendência, dentro do embate científico, foi a de especialização das diferentes áreas do conhecimento. Neste âmbito, a noção de Paisagem como sendo um conceito totalizante resultado da "conexão entre várias esferas" (VITTE, 2007, 75p.) acaba se esvaziando dando lugar ao termo paisagem seguido de adjetivos como natural, florestal, cultural, urbana, etc. Se por um lado o positivismo gerou o desenvolvimento vertical das ciências e, consequentemente, um grande avanço nas condições de vida da sociedade, por outro reforçou a ideia de que a natureza seria um recurso a ser utilizado pelo ser humano, e assim deve ser quantificada e classificada, deste modo a visão do todo e de que o ser humano faz parte da natureza é suprimida pelo antropocentrismo (TOMASONI, 2004; NAVES e BERNARDES, 2014).

Na primeira metade do século XX, com base na Teoria Geral dos Sistemas e com o início dos embates sobre os problemas ambientais globais e consequente busca pela relação dos organismos com o seu meio, o conceito de Paisagem é retomado na Geografia buscando evidenciar o caráter integrador de outrora, atentando à complexidade das relações que a configuram para poder compreender os sistemas terrestres (ABRAHÃO, 2009; SUERTEGARAY e NUNES, 2001; SANTOS, 2004; TOMASONI, 2004). Isso fica evidente em diferentes propostas metodológicas como a de Sotchava ${ }^{1}$ (1977) em que a Geografia, à luz da teoria sistêmica, buscaria identificar as conexões entre os elementos da natureza servindo inclusive ao planejamento. Nessa questão, outro importante autor, Bertrand ${ }^{2}$ (2004), propõe um modelo teórico da Paisagem voltado para a síntese, representada pelo Geossistema/Paisagem resultado da interação entre o potencial ecológico, exploração biológica e ação antrópica (Figura 1), e também, um sistema taxonômico para classificar a Paisagem Global.

\footnotetext{
${ }_{1}^{1}$ Publicado originalmente em 1976 pela "Reports of the Institute of Geography of Siberia and Far West", Irkutsk, volume especial, p. 3-40. Traduzido e publicado no Brasil por Carlos Augusto Figueiredo Monteiro e Dora de Amarante Romariz no periódico "Métodos em Questão", São Paulo, 1977.

2 Publicado originalmente em 1968 pela "Revue Geógraphique des Pyrénées et du Sud-Ouest", Toulouse, v. 39 n. 3, p. $249-272$.

Traduzido e publicado no Brasil no "Caderno de Ciências da Terra". Instituto de Geografia da USP, n. 13, 1972. Republicado na revista "RA'E GA", Curitiba, n. 8, p. 141-152, 2004.
} 
Figura 1. Modelo teórico da conformação do Geossistema/Paisagem. Fonte: Bertrand (2004).

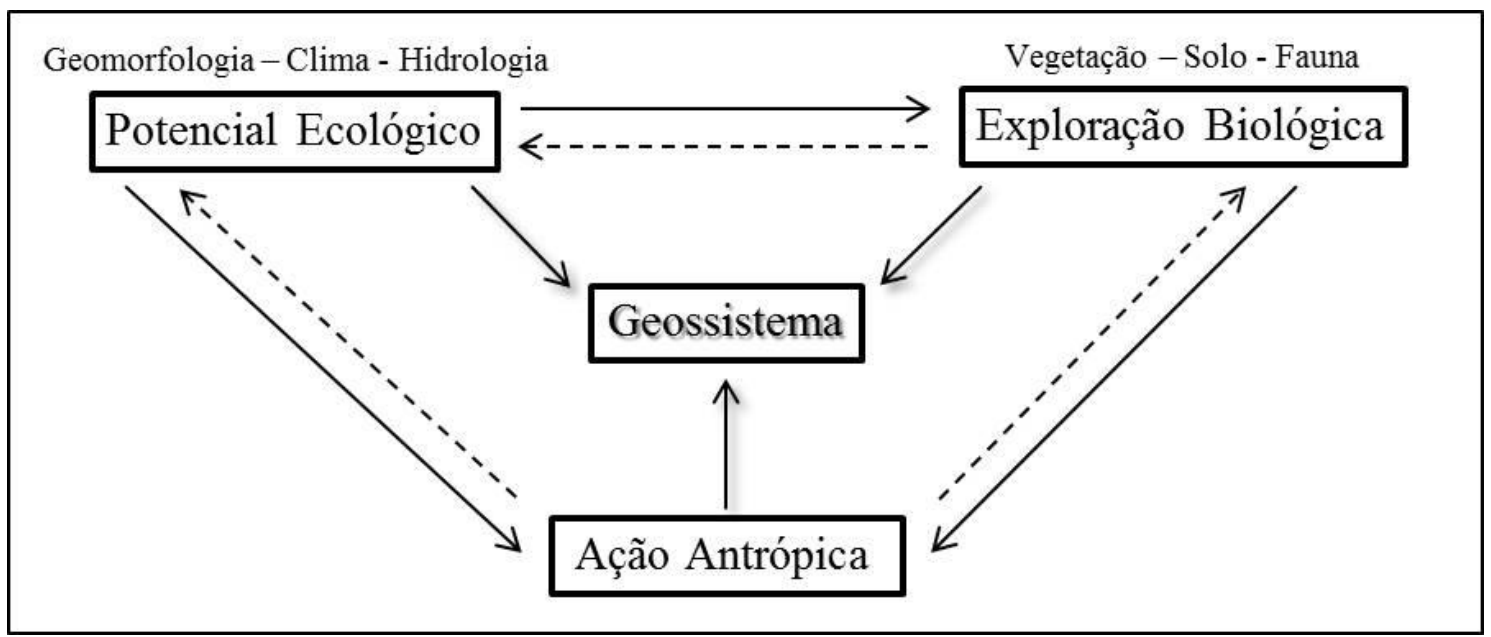

Ainda em relação à compreensão da paisagem como um sistema, segundo Naveh e Lieberman (1984) e Zonneveld e Forman (1990) há quatro formas de abordagem:

- Visual: estético, cênico, voltado aos estudos na Arquitetura da Paisagem;

- Corológico (horizontal): atrelado a espacialização de unidades de paisagem, abordagem proveniente da Geografia por meio da cartografia voltada à paisagem. É a relação espacial, horizontal, da paisagem.

- Topológica (vertical): a perspectiva ecológica é mais enfática, nesta abordagem. Estudos verticalizados sobre aspectos da paisagem, remete às disciplinas tradicionais como a Pedologia, Geomorfologia, Zoologia, dentre outras.

- Evolutivo: trata-se do aspecto temporal da paisagem.

Porém, segundo esses autores, todos esses aspectos são, de fato, inseparáveis e devem ser, de uma forma ou de outra, considerados conjuntamente nos estudos sobre paisagem.

Naveh e Lieberman (1984) sugerem o conceito Total Human Ecosystem (THE) - como um supersistema físico-geosférico, mental e espiritual, no qual os homens seriam integrados com seu ambiente total, e que este deveria ser considerado o maior paradigma holístico da Ecologia da Paisagem. O THE seria considerado o mais alto nível de integração ecológica (NUCCl, 2007).

Atualmente, em um planeta cada vez mais problemático em relação, dentre outros, a sua condição ambiental, emergem, novamente, propostas de síntese, com observação do todo e não apenas das partes (CAPRA, 2002; TOLEDO, 2008; HARDING, 2008). No que confere ao conceito de Paisagem e a sua história como 
objeto de estudo, pode-se dizer que no século XX ela passou de uma visão cartesiana e mecanicista para outra sistêmica e integrada, o que reflete a própria noção de como mudou a relação entre a sociedade e a natureza (MEZZOMO e NÓBREGA, 2008).

Para Ferreira (2010), o estudo da Paisagem nos dias atuais configura uma tentativa metodológica conectiva que se torna útil ao evidenciar o fluxo de matéria e energia resultante da interação entre elementos naturais e antrópicos, e que podem afetar a qualidade ambiental. Em relação aos estudos da paisagem com foco na qualidade ambiental, Monteiro (1987) apresenta um exemplar mapeamento de síntese, acompanhado de um complexo quadro de correlações que busca mostrar os elementos da paisagem em interação e, como objetivo final a qualidade ambiental no Recôncavo Baiano. Nucci (1996), inspirado no trabalho de Monteiro (1987) e na teoria do Planejamento da Paisagem, entre outros, desenvolve um método de mapeamento da qualidade ambiental, em escala de detalhe e voltado para áreas urbanas.

Especificamente no caso da Alemanha, o Planejamento da Paisagem torna-se lei, voltada para o ordenamento territorial tanto em áreas rurais quanto urbanas, tendo como pressupostos básicos salvaguardar a diversidade animal e vegetal, do meio físico, bem como a paisagem. Preocupa-se com os espaços livres voltados para conservação e contemplação, regulação do uso e manutenção dos recursos naturais (água, solos, vegetação, clima) e ainda em estabelecer metas de avaliação de impactos ambientais e para a avaliação da qualidade ambiental (WILKE, et al., 2002; HAAREN, et al., 2008).

A delimitação de unidades de paisagem (UPs), nesse escopo, aparece como uma possibilidade de atrelar a discussão em torno do conceito de Paisagem de ordem sistêmica e integral aos princípios do Planejamento da Paisagem. Portanto, a delimitação de UPs torna-se relevante para diagnosticar as potencialidades de uso e ocupação da terra bem como os anseios da população. O conceito de Paisagem se mostra valoroso quando a perspectiva de síntese é proposta, Monteiro (2000) em sua obra reflexiva sobre os estudos geossistêmicos define paisagem como:

Entidade espacial delimitada, segundo um nível de resolução do pesquisador, a partir dos objetivos centrais da análise, de qualquer modo, sempre resultado de integração dinâmica e, portanto, instável dos elementos de suporte, forma e cobertura (físicas, biológicas e antrópicas), expressa em partes delimitáveis infinitamente, mas individualizadas através das relações entre elas que organizam um todo complexo (sistema); verdadeiro conjunto solidário em perpétua evolução. (MONTEIRO, 2000, p. 39).

Esta definição torna-se acessível à prática da delimitação de unidades de paisagem uma vez que coloca sob responsabilidade do pesquisador, em função dos objetivos da pesquisa, a proporção espacial abordada e até mesmo o uso a que se destinarão as unidades mapeadas.

Com Bertrand (2004), bem como com Sotchava (1977), surgiram propostas mais elaboradas, porém complexas e sem uma real aplicabilidade a realidade brasileira (NUCCl, 2008). A proposta de Monteiro (2000), 
sendo elegante e simples, evita a confusão entre termos técnicos complexos propostos como: Biótopos, Geótopos, Geômeros, Ecótopos, entre outros, substituídos, então, pela denominação “Unidades de Paisagem” acrescida da escala em que foram identificadas.

Cavalcanti (2014), nesse sentido, comenta que os diferentes métodos para o mapeamento da paisagem devem servir de referência, mas sua aplicação deve atentar para as especificidades locais sob o risco de não refletirem a realidade. Mezzomo e Nóbrega (2008) expõem que é possível utilizar um elemento de destaque na paisagem, e a partir deles identificar as relações entre os elementos, para estabelecer as UPs. Para Delpoux (1974), devem-se buscar homogeneidades que evidenciem o suporte e a cobertura da paisagem. Pode-se perceber que a delimitação de UPs parte de um pressuposto básico: um ato de distinção, que é realizado a todo momento pela necessidade, do ser humano, de distinguir objetos a seu interesse (MATURANA e VARELA, 1995).

A delimitação das UPs, portanto, considera diferentes tipos de dados com características bióticas, abióticas e antrópicas. Essa grande quantidade e variedade de dados ocasionam certa dificuldade no que tange aos procedimentos de generalização utilizados para elaborar os mapas de UPs (PUEBLA, SALINAS-CHAVEZ e NOA, 2009).

Uma possibilidade é o uso da cartografia de síntese. Sua utilização pode evidenciar a relação intrínseca dos elementos que compõem a paisagem e ainda sua dinâmica por advento de temporalidade e, assim, tendo a capacidade de aglutinar informações de diferentes fontes, escalas e qualidades geradas a partir de estudos específicos de caráter analítico, para promover uma síntese que resulte em unidades de paisagem (ZACHARIAS et al., 2009).

Neste âmbito, a proposta de McHarg (1971), que com base em mapeamentos dos elementos do meio físico e biológico e, posteriormente, utilizando o método de sobreposição de cartas, possibilita uma integração desses elementos, indicando, no caso, a susceptibilidade das unidades de paisagem aos diferentes usos da terra.

A respeito da cartografia de síntese, Martinelli (2006, p.90) expõe que muitos profissionais ainda realizam sobreposições de inúmeros atributos e não desenvolvem os mapas das devidas sínteses, que resultariam em unidades espaciais, mas apenas reproduzem os elementos sobrepostos em mapas confusos com hachuras, cores, símbolos em demasia, negando a essência da síntese. Para o autor (op. cit.) a cartografia de síntese deve mostrar um novo resultado, uma nova legenda que evidencie as unidades espaciais geradas justamente pela síntese dos dados.

No entanto, um mapa de síntese que seja voltado para a expressão de diferentes paisagens precisa de complementos para sua compreensão. Cavalcanti (2014) descreve diferentes formas de se identificar as 
unidades de paisagem, dentre elas expõe a proposta do "Quadro de Correlação". Tal ferramenta serve para a compreensão dos elementos que compõem cada UP. Essa ferramenta, entretanto, não é algo novo, no Brasil um exemplo de aplicação foi o trabalho de Monteiro e equipe no Recôncavo Baiano (1987), cujo resultado final traz um mapa acompanhado de um quadro correlativo minuciosamente discutido, como citado anteriormente. McHarg (1971), também trabalha com quadros, perfis e até tabelas de correlação atentando justamente à integração com a cartografia desenvolvida.

Portanto, o trabalho de delimitação e de análise sistêmica de unidades de paisagem envolve uma grande quantidade de dados espaciais em função da complexidade que envolve a paisagem. Com o advento da tecnologia uma ferramenta que auxilia nas sínteses necessárias é o Sistema de Informações Geográficas (SIG), que para Puebla et al (2009):

Llegar a la delimitación, clasificación y cartografía de los paisajes constituye un arduo trabajo, en los que el uso de los SIG es de gran ayuda, ya que permite contar con una serie de elementos, (...), dándonos la posibilidad de integrar toda la información en un mapa preliminar de paisajes (...) (PUEBLA, SALINAS-CHAVEZ e NOA, 2009, p. 97).

A partir do que foi revisado anteriormente em relação ao conceito de Paisagem, à importância do Planejamento da Paisagem, tal qual da delimitação das UPs, a cartografia de síntese, bem como os SIGs, tornam-se uma possibilidade técnica de viabilizar tais estudos, como o proposto para o bairro de Santa Felicidade, Curitiba-PR.

\section{MÉTODO}

Santa Felicidade é um bairro localizado no noroeste do município de Curitiba, no limite com o município de Almirante Tamandaré. (Figura 2).

Com uma área em torno de $12,27 \mathrm{~km}^{2}$, é o sexto maior bairro, o que equivale a 2,85\% do município (IPPUC, 2012). Sua escolha como objeto de estudos ocorreu em função da sua diversidade de paisagens.

Admitiu-se o conceito de Paisagem de Monteiro (2000), que, apesar de ter muitas aproximações com o entendimento de Bertrand (2004), facilita o modo de classificação da paisagem tornando-a mais funcional do ponto de vista do mapeamento. Esta aplicabilidade do conceito de Paisagem de Monteiro (op. cit.) é complementada nesta pesquisa, no momento da delimitação das UPs, pela busca de homogeneidades na paisagem (DELPOUX, 1974; MATURANA e VARELA, 1995).

Ainda como fundamentos teóricos estão as premissas do Planejamento da Paisagem, como a manutenção das funções ecológicas e capacidade de regeneração natural, uso sustentável e conservação 
(fauna, flora, solos, águas, ecossistemas, paisagens) e de salvaguardar a diversidade de paisagens (KIEMSTEDT et al., 1998; ALEMANHA, 2002; HAAREN, et al., 2008).

Figura 2. Mapa de localização do bairro Santa Felicidade, Curitiba-PR. Fonte: Valaski (2008).

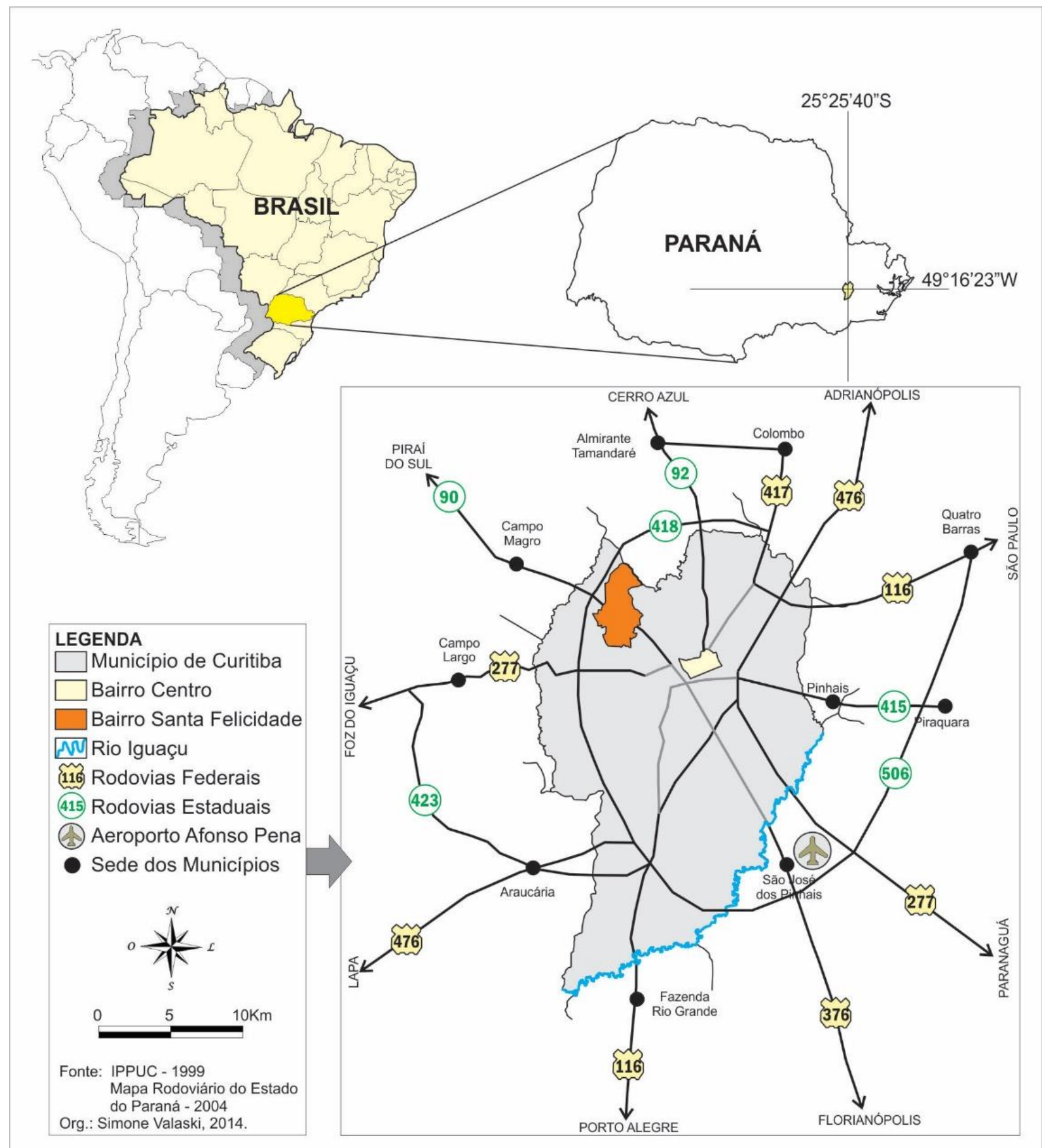


Portanto, a discussão assume alguns pressupostos: a Paisagem/Geossistema, as homogeneidades da Paisagem e os princípios do Planejamento da Paisagem. A figura 2 organiza as principais obras e conceitos abordados com fins de delimitação das UPs.

Em relação aos procedimentos adotados primeiramente foi realizada a aquisição de produtos cartográficos junto aos órgãos oficiais de planejamento do município e região, a saber, Instituto de Pesquisa e Planejamento Urbano de Curitiba (IPPUC) e Coordenação da Região Metropolitana de Curitiba (COMEC). Em seguida foram organizados os dados de iniciações científicas, monografias de conclusão de curso de graduação, mestrados e doutorados pertinentes ao grupo de Planejamento da Paisagem (DEGEOG-UFPRCNPq) e que se encontram disponíveis para consulta em Nucci (2010) e ainda foram levantados dados e pesquisas realizadas fora do escopo do grupo (Fluxograma 1).

Figura 2. Fundamentação teórica utilizada. Fonte: Os autores.

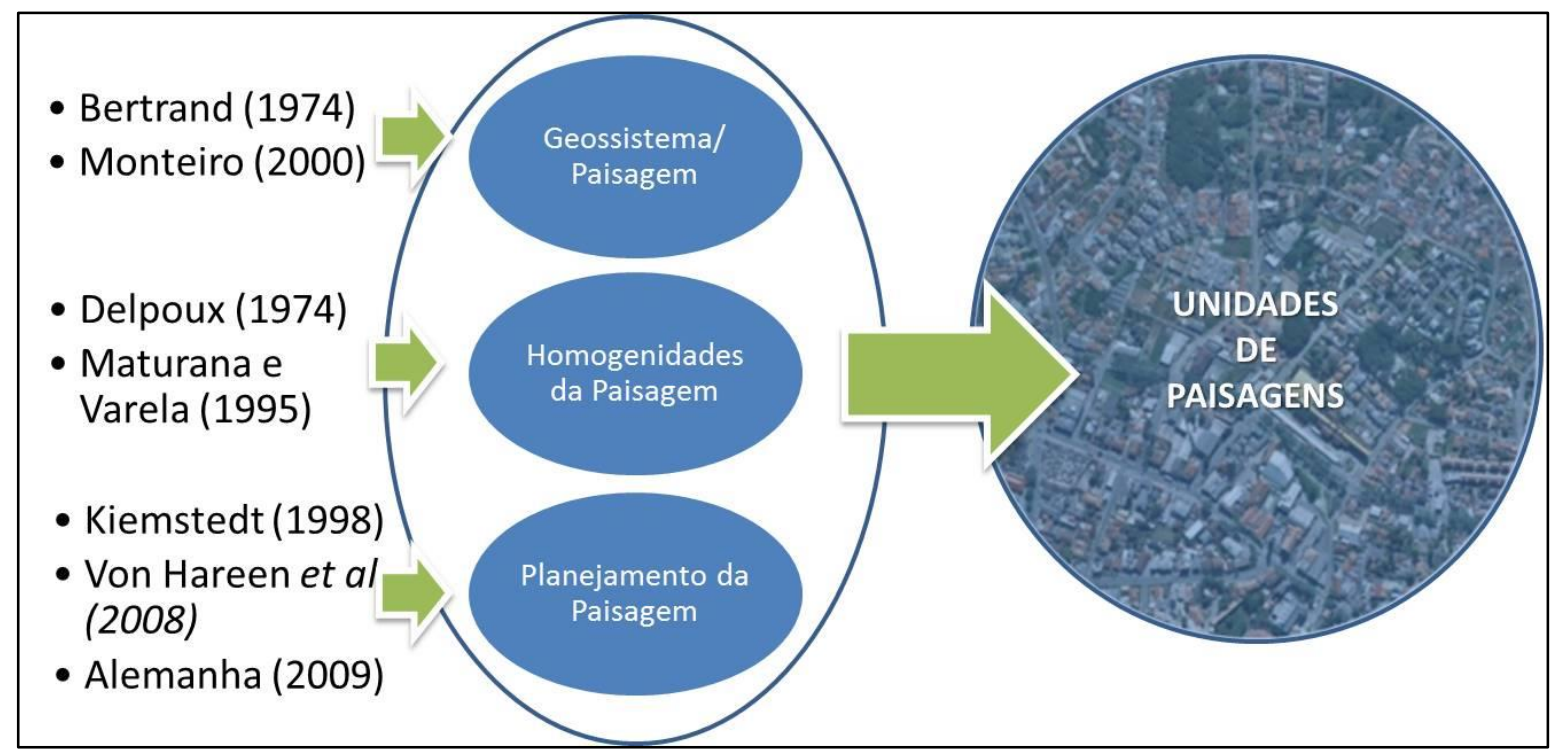

Os dados foram, então, padronizados tanto em relação aos formatos digitais, quanto a compatibilidade de escalas e foi organizado um SIG para o bairro aglutinando no mesmo ambiente virtual as diferentes informações cartografáveis disponíveis e levantadas (Fluxograma 1). Posteriormente, foram gerados os produtos: a Carta de Unidades de Paisagem Originais e, com base nela e com a inclusão de dados sobre a ação antrópica, a Carta de Unidades de Paisagem, juntamente com o Quadro de Correlações das Unidades de Paisagem do bairro de Santa Felicidade (Fluxograma 1.).

A delimitação das UPs contou ainda com intenso trabalho de campo para redução dos erros e verificação, sendo percorridas todas as ruas e avenidas do bairro ao longo de cinco meses. 
Destaca-se que a escala de trabalho utilizada (1:8.000) tem relação direta com a disponibilidade dos dados, majoritariamente do grupo de pesquisa em "Planejamento da Paisagem", que estão em escalas grandes entre 1:10.000 e 1:8.000, o que é positivo para este trabalho uma vez que apresentam muitos detalhes, como visualização de lotes, o que escalas menores ocultariam.

Fluxograma 1. Dados utilizados e sínteses parciais para a delimitação das Unidades de Paisagem do bairro Santa Felicidade, CuritibaPR. Fonte: Os autores.

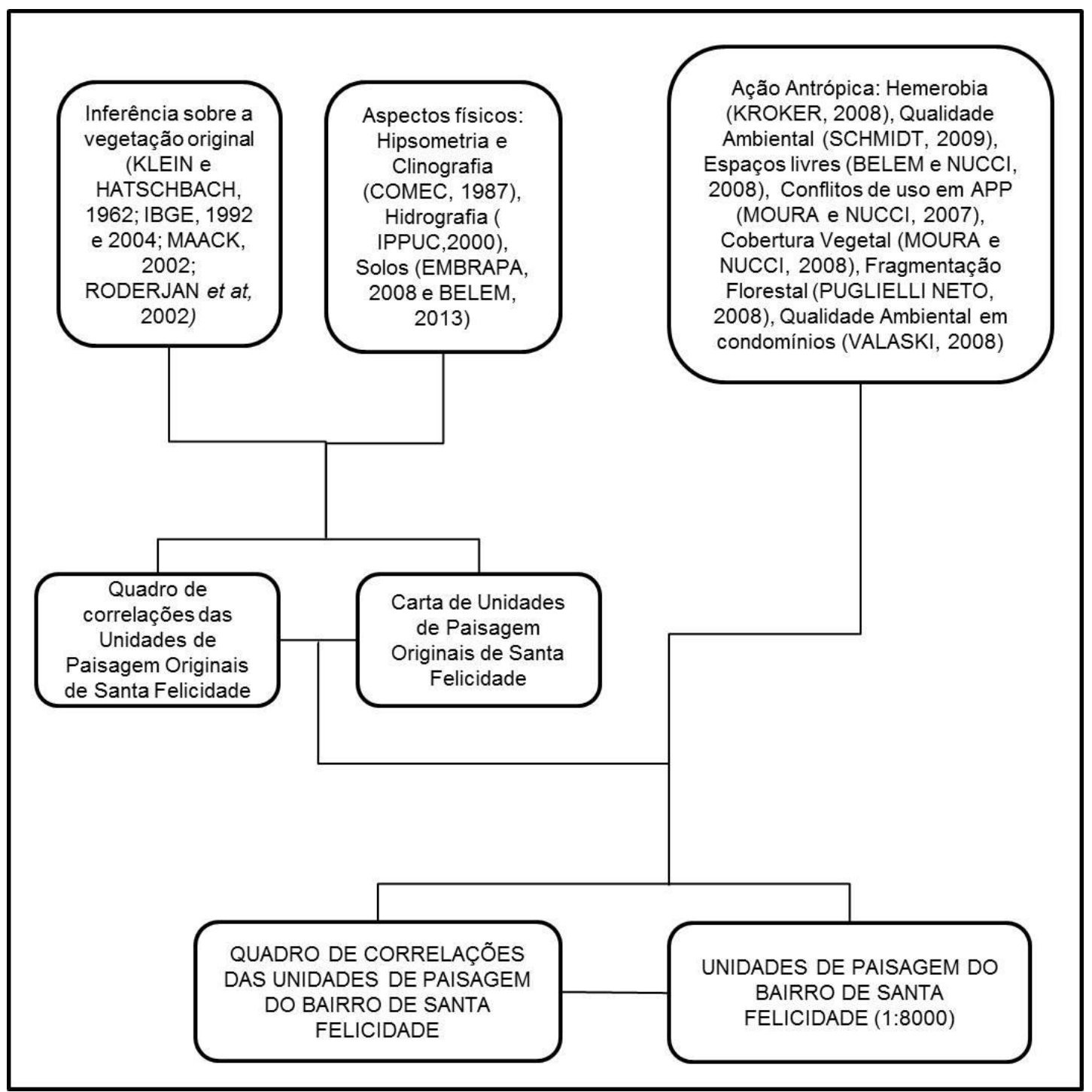

\section{Resultados e Discussão}

Os resultados apresentam dois conjuntos de produtos: as Unidades de Paisagem Originais (UPO) e o quadro correlativo correspondente (Figura 3, Quadro 1) e as Unidades de Paisagem do bairro Santa Felicidade e seu quadro correlativo completo (Figura 4, Quadro 2.1 e 2.2). 
Figura 3. Unidades de Paisagem Originais do Bairro Santa Felicidade, Curitiba-PR. Fonte: Os autores.

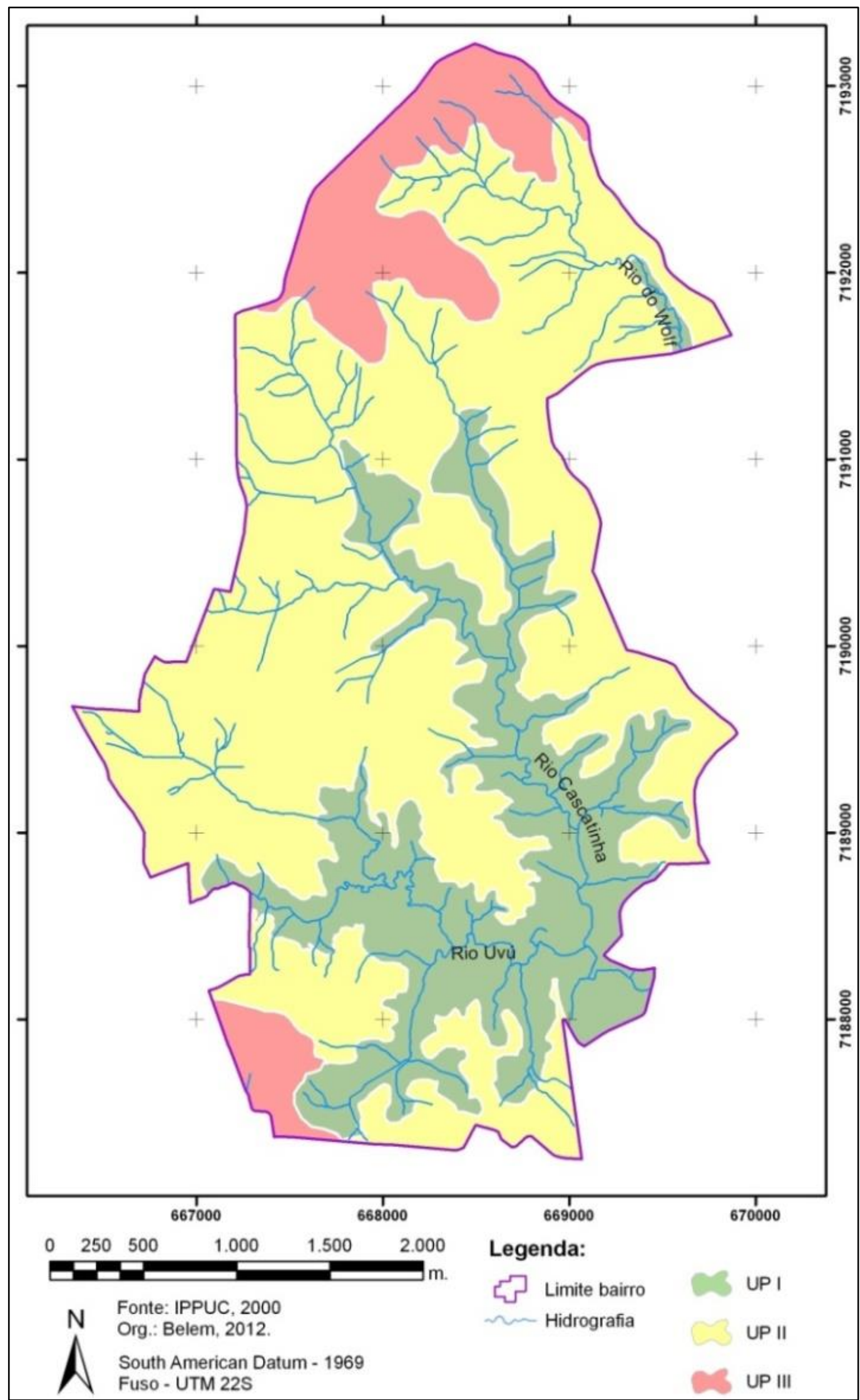


Quadro 1. Quadro de correlações entre os elementos das Unidades de Paisagem Originais do bairro Santa Felicidade, Curitiba-PR. Fonte: Os autores.

\begin{tabular}{|c|c|c|c|c|c|c|}
\hline UPO & Formas & Hipsometria & Clinografia & Solos & Hidrografia & $\begin{array}{l}\text { Vegetação } \\
\text { potencial }\end{array}$ \\
\hline UPO I & $\begin{array}{l}\text { Vales em V com } \\
\text { planícies de fundo } \\
\text { de vale e aluviões } \\
\text { associados. }\end{array}$ & $\begin{array}{l}900-945 \mathrm{~m} . \\
\text { a.n.m. } \\
\text { aprox. }\end{array}$ & $\begin{array}{c}\text { Altas } \\
\text { declividades } \\
\text { subsequentes } \\
\text { aos fundos de } \\
\text { vales planos }\end{array}$ & $\begin{array}{l}\text { Solos associados à } \\
\text { Formação } \\
\text { Guabirotuba. } \\
\text { Cambissolos } \\
\text { Flúvicos e Háplicos }\end{array}$ & $\begin{array}{c}\text { Terço médio dos principais } \\
\text { rios, onde há a maior } \\
\text { confluência das águas } \\
\text { rumo ao rio Barigui; e } \\
\text { consequentes áreas de } \\
\text { inundação. } \\
\end{array}$ & $\begin{array}{c}\text { Floresta } \\
\text { Ombrófila Mista } \\
\text { Aluvial e } \\
\text { Montana }\end{array}$ \\
\hline UPO II & $\begin{array}{c}\text { Média vertente } \\
\text { com Vertentes } \\
\text { côncavas. }\end{array}$ & $\begin{array}{l}\text { 946-980 m. } \\
\text { a.n.m. } \\
\text { aprox. }\end{array}$ & $\begin{array}{l}\text { Declives } \\
\text { suaves }\end{array}$ & $\begin{array}{c}\text { Cambissolos } \\
\text { Háplicos, } \\
\text { característicos } \\
\end{array}$ & $\begin{array}{l}75 \text { das } 102 \text { nascentes se } \\
\text { encontram nesta unidade. }\end{array}$ & $\begin{array}{c}\text { Floresta } \\
\text { Ombrófila Mista } \\
\text { Montana. }\end{array}$ \\
\hline UPO III & $\begin{array}{c}\text { Áreas } \\
\text { preferencialmente } \\
\text { de topos planos. }\end{array}$ & $\begin{array}{c}981 \mathrm{a} \\
1006 \mathrm{~m} . \\
\text { a.n.m. }\end{array}$ & $\begin{array}{l}\text { Declividades } \\
\text { suaves à } \\
\text { planas. }\end{array}$ & $\begin{array}{l}\text { Solos profundos, } \\
\text { em maioria } \\
\text { Latossolos Brunos. }\end{array}$ & $\begin{array}{l}\text { Divisores de águas, poucas } \\
\text { drenagens perenes } \\
\text { aparecem nesta unidade. }\end{array}$ & $\begin{array}{c}\text { Floresta } \\
\text { Ombrófila Mista } \\
\text { Montana e } \\
\text { presença de } \\
\text { campos. }\end{array}$ \\
\hline
\end{tabular}

Desta forma, realizadas a introdução de diversos estudos relativos ao meio antrópico e suas atividades (Fluxograma 1) e visando a síntese junto aos elementos físicos e bióticos da paisagem (caracterizados nas UPO), como apresentado nos procedimentos, encontraram-se quatro Unidades de Paisagens (Figura 4 e quadro 2). 
Figura 4. Unidades de Paisagem Originais do Bairro Santa Felicidade, Curitiba-PR. Fonte: Os autores.

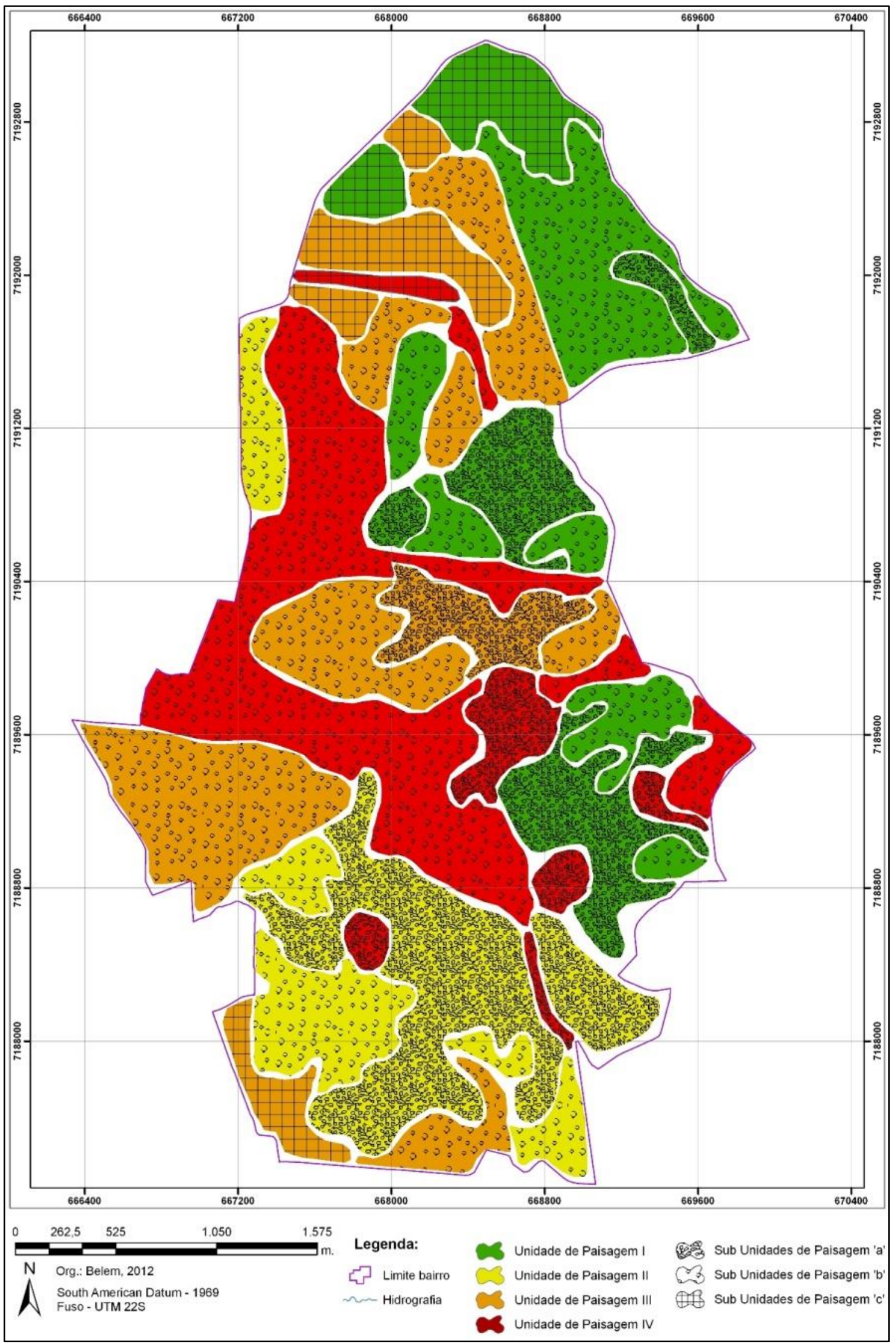


Quadro 2.1. Quadro de correlações entre os elementos das UPs do bairro Santa Felicidade, Curitiba-PR. Fonte: Os autores.

\begin{tabular}{|c|c|c|c|c|c|c|}
\hline UP & Sub-UP & Hemerobia & $\begin{array}{l}\text { Qualidade } \\
\text { ambiental }\end{array}$ & Formas do relevo & $\begin{array}{l}\text { Hipso- } \\
\text { metria }\end{array}$ & Clinografia \\
\hline \multirow{3}{*}{ UP - I } & UP - la & \multirow{3}{*}{$\begin{array}{c}\text { Dependência } \\
\text { energética e } \\
\text { tecnológica mínima } \\
\text { encontrada. As funções } \\
\text { ecológicas ainda estão } \\
\text { estabelecidas bem } \\
\text { como a capacidade de } \\
\text { resiliência. }\end{array}$} & \multirow{3}{*}{$\begin{array}{l}\text { Varia da classe } \\
\text { que contém } \\
\text { nenhum atributo } \\
\text { negativo até a } \\
\text { classe com dois } \\
\text { atributos. }\end{array}$} & $\begin{array}{c}\text { Vales em V com } \\
\text { encostas declivosas e } \\
\text { planícies de fundo de } \\
\text { vale com pequenas } \\
\text { áreas de aluviões } \\
\text { associadas. }\end{array}$ & $\begin{array}{l}900-945 \\
\text { m. a.n.m. } \\
\text { aprox. }\end{array}$ & $\begin{array}{c}\text { Altas declividades } \\
\text { chegando a } 45^{\circ} \mathrm{e} \\
\text { também fundos de } \\
\text { vales planos que } \\
\text { chegam a menos de } \\
3^{\circ} .\end{array}$ \\
\hline & UP - Ib & & & $\begin{array}{l}\text { Média vertente com } \\
\text { predomínio de } \\
\text { vertentes côncavas. }\end{array}$ & $\begin{array}{l}\text { 946-980 m. } \\
\text { a.n.m. } \\
\text { aprox. }\end{array}$ & $\begin{array}{l}\text { Declives variando } \\
\text { entre } 8^{\circ} \text { e } 20^{\circ} \\
\text { chegando a acima } \\
\text { de } 45^{\circ} \text { na transição } \\
\text { com áreas de topos. }\end{array}$ \\
\hline & UP - Ic & & & $\begin{array}{l}\text { Áreas } \\
\text { preferencialmente de } \\
\text { topos planos. }\end{array}$ & $\begin{array}{l}\text { 981- acima } \\
\text { de } 1000 \mathrm{~m} . \\
\text { a.n.m. } \\
\text { aprox. }\end{array}$ & $\begin{array}{c}\text { Declividades suaves } \\
\text { próximas a } \\
\text { plenitude. Variando } \\
\text { de } 1 \text { a } 8^{\circ} .\end{array}$ \\
\hline \multirow[t]{2}{*}{ UP - II } & UP - IIa & \multirow{2}{*}{$\begin{array}{l}\text { Contém áreas que } \\
\text { variam de muito baixa a } \\
\text { média dependência } \\
\text { energética e } \\
\text { tecnológica. Algumas } \\
\text { pequenas manchas } \\
\text { acima disso são } \\
\text { perceptíveis. De modo } \\
\text { geral as funções } \\
\text { ecológicas ainda são } \\
\text { mantidas }\end{array}$} & \multirow{2}{*}{$\begin{array}{c}\text { Apresenta uma } \\
\text { variação principal } \\
\text { que vai da classe } \\
\text { mais baixa } \\
\text { encontrada até as } \\
\text { classes } 3 \text { e } 4 . \\
\text { Algumas } \\
\text { pequenas áreas } \\
\text { com classe } 5 \\
\text { também foi } \\
\text { encontrada. }\end{array}$} & $\begin{array}{l}\text { Área de planície com } \\
\text { aluviões associados e } \\
\text { encostas declivosas }\end{array}$ & $\begin{array}{l}900-945 \\
\text { m. a.n.m. } \\
\text { aprox. }\end{array}$ & $\begin{array}{c}\text { Altas declividades } \\
\text { chegando a } 45^{\circ} \mathrm{e} \\
\text { também fundos de } \\
\text { vales planos que } \\
\text { chegam a menos de } \\
3^{\circ} \text {. }\end{array}$ \\
\hline & $U P-I I b$ & & & $\begin{array}{l}\text { Média vertente com } \\
\text { predomínio de } \\
\text { formas côncavas. }\end{array}$ & $\begin{array}{l}\text { 946-980 m. } \\
\text { a.n.m. } \\
\text { aprox. }\end{array}$ & $\begin{array}{c}\text { Declives suaves } \\
\text { variando de } 3 \text { a } 20^{\circ} \\
\text { em média. }\end{array}$ \\
\hline \multirow{3}{*}{ UP - III } & UP - IIIa & \multirow{3}{*}{$\begin{array}{l}\text { Áreas com hemerobia } \\
\text { predominantemente de } \\
\text { classe alta, mas com } \\
\text { pequenas áreas } \\
\text { variando de muito } \\
\text { baixa a máxima } \\
\text { encontrada. Perda } \\
\text { significativa de funções } \\
\text { ecológicas. }\end{array}$} & \multirow{3}{*}{$\begin{array}{l}\text { Predomínio da } \\
\text { classe 4, mas com } \\
\text { bastante } \\
\text { recorrência da } \\
\text { classe } 3 . \text { E maior } \\
\text { presença da } \\
\text { classe } 5 \text { em } \\
\text { relação a UP II. }\end{array}$} & $\begin{array}{c}\text { Vales em V com } \\
\text { encostas declivosas e } \\
\text { planícies de fundo de } \\
\text { vale com pequenas } \\
\text { áreas de aluviões } \\
\text { associadas. }\end{array}$ & $\begin{array}{l}900-945 \\
\text { m. a.n.m. } \\
\text { aprox. }\end{array}$ & $\begin{array}{c}\text { Altas declividades } \\
\text { chegando a } 45^{\circ} \mathrm{e} \\
\text { também fundos de } \\
\text { vales planos que } \\
\text { chegam a menos de } \\
3^{\circ} \text {. }\end{array}$ \\
\hline & UP - IIIb & & & $\begin{array}{l}\text { Média vertente com } \\
\text { predomínio de } \\
\text { vertentes côncavas. }\end{array}$ & $\begin{array}{l}\text { 946-980 m. } \\
\text { a.n.m. } \\
\text { aprox. }\end{array}$ & $\begin{array}{l}\text { Declives suaves } \\
\text { entre } 3 \text { e } 20^{\circ} .\end{array}$ \\
\hline & UP - IIIC & & & $\begin{array}{l}\text { Áreas } \\
\text { preferencialmente de } \\
\text { topos planos. }\end{array}$ & $\begin{array}{l}\text { 981- acima } \\
\text { de } 1000 \mathrm{~m} . \\
\text { a.n.m. } \\
\text { aprox. }\end{array}$ & $\begin{array}{c}\text { Declividades suaves } \\
\text { próximas a } \\
\text { plenitude. Variando } \\
\text { de } 1 \text { a } 8^{\circ} \text {; existem } \\
\text { pequenas áreas } \\
\text { chegando até } 20^{\circ} .\end{array}$ \\
\hline \multirow{3}{*}{ UP - IV } & UP - IVa & \multirow{3}{*}{$\begin{array}{c}\text { Dependência } \\
\text { energética e de } \\
\text { tecnologia para a } \\
\text { manutenção nas classes } \\
\text { alta, muito alta, e } \\
\text { máximas encontradas. } \\
\text { Alta perda das funções } \\
\text { ecológicas. }\end{array}$} & \multirow{3}{*}{$\begin{array}{c}\text { Classe } 5 \text { aparece } \\
\text { mais } \\
\text { constantemente } \\
\text { junto com a } \\
\text { classe } 4 \text {. No } \\
\text { entanto as classes } \\
6 \text { e } 7 \text { aparecem a } \\
\text { NW. }\end{array}$} & $\begin{array}{c}\text { Áreas de planície de } \\
\text { inundação do rio } \\
\text { Cascatinha. }\end{array}$ & $\begin{array}{l}900-945 \\
\text { m. a.n.m. } \\
\text { aprox. }\end{array}$ & $\begin{array}{c}\text { Altas declividades } \\
\text { chegando a } 45^{\circ} \mathrm{e} \\
\text { também fundos de } \\
\text { vales planos que } \\
\text { chegam a menos de } \\
3^{\circ} \text {. }\end{array}$ \\
\hline & $U P-I V b$ & & & $\begin{array}{l}\text { Média vertente com } \\
\text { vertentes côncavas; e } \\
\text { divisores em altitude } \\
\text { média. }\end{array}$ & $\begin{array}{l}\text { 946-980 m. } \\
\text { a.n.m. } \\
\text { aprox. }\end{array}$ & $\begin{array}{c}\text { Declives que variam } \\
\text { de } 3 \text { a } 20^{\circ} .\end{array}$ \\
\hline & $U P-I V c$ & & & $\begin{array}{l}\text { Pequena área de topo } \\
\text { plano. }\end{array}$ & $\begin{array}{l}\text { 981- acima } \\
\text { de } 1000 \mathrm{~m} . \\
\text { a.n.m. }\end{array}$ & $\begin{array}{l}\text { Declividades que } \\
\text { vão de } 8 \text { a } 20^{\circ} .\end{array}$ \\
\hline
\end{tabular}


Quadro 2.2. Quadro de correlações entre os elementos das UPs do bairro Santa Felicidade, Curitiba-PR. Fonte: Os autores.

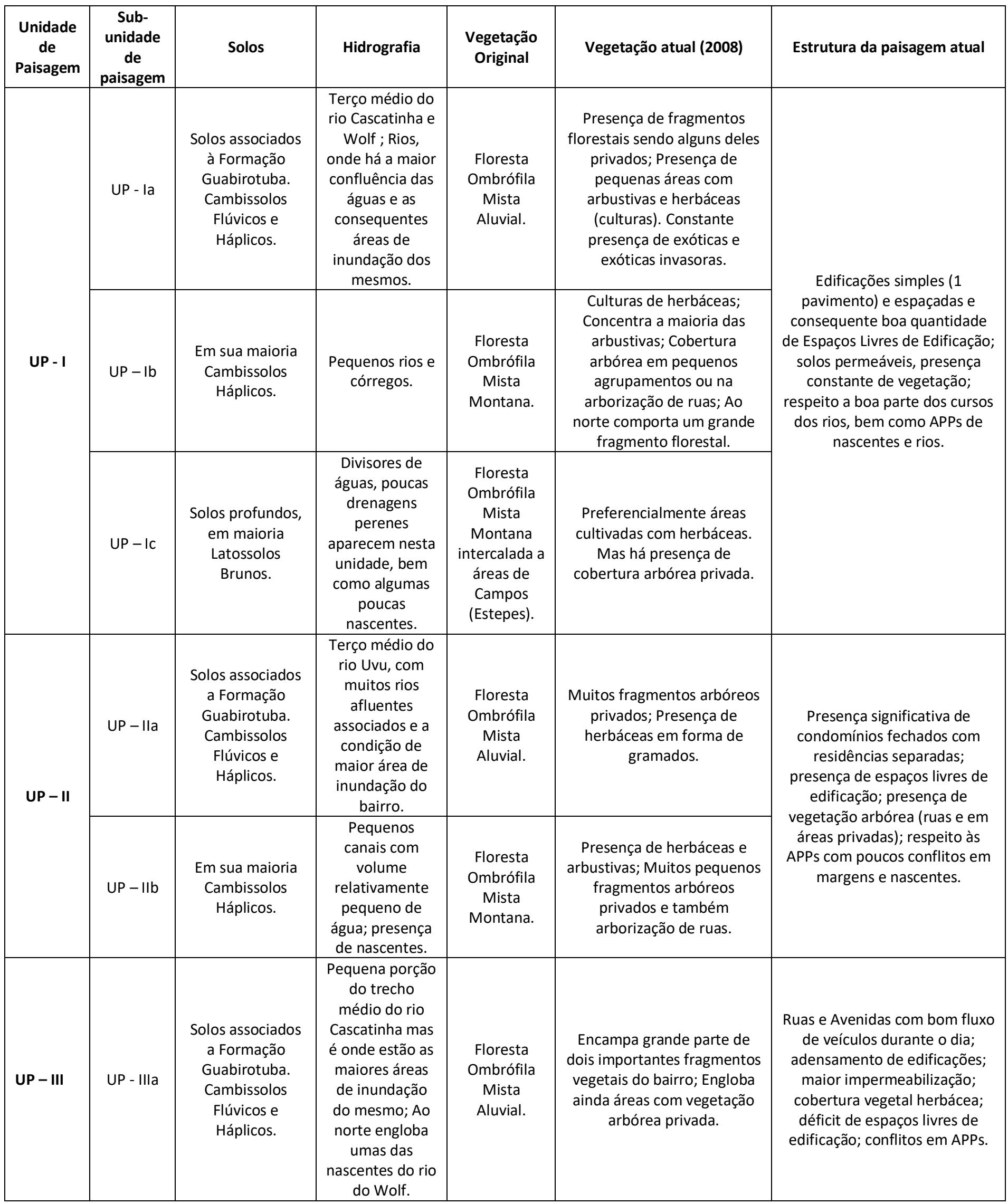




\begin{tabular}{|c|c|c|c|c|c|c|}
\hline & UP - IIIb & $\begin{array}{l}\text { Em sua maioria } \\
\text { Cambissolos } \\
\text { Háplicos. }\end{array}$ & $\begin{array}{l}\text { Terço superior } \\
\text { dos rios e } \\
\text { córregos que } \\
\text { alimentos os } \\
\text { principais rios } \\
\text { do bairro; } \\
\text { grande parte } \\
\text { das nascentes } \\
\text { existentes. } \\
\end{array}$ & $\begin{array}{l}\text { Floresta } \\
\text { Ombrófila } \\
\text { Mista } \\
\text { Montana. }\end{array}$ & $\begin{array}{l}\text { Pequenos conjuntos vegetais } \\
\text { privados, e arborização de } \\
\text { ruas; áreas com culturas e } \\
\text { áreas com gramados } \\
\text { compõe as herbáceas } \\
\text { presentes. }\end{array}$ & \\
\hline & UP - IIIC & $\begin{array}{l}\text { Solos profundos, } \\
\text { em maioria } \\
\text { Latossolos } \\
\text { Brunos. }\end{array}$ & $\begin{array}{c}\text { Áreas de } \\
\text { infiltração } \\
\text { devido aos solos } \\
\text { profundos e da } \\
\text { plenitude; } \\
\text { pequenos } \\
\text { córregos e } \\
\text { presença de } \\
\text { algumas poucas } \\
\text { nascentes. }\end{array}$ & $\begin{array}{l}\text { Floresta } \\
\text { Ombrófila } \\
\text { Mista } \\
\text { Montana } \\
\text { intercalada a } \\
\text { áreas de } \\
\text { Campos } \\
\text { (Estepes). }\end{array}$ & $\begin{array}{c}\text { Presença de arborização de } \\
\text { ruas. }\end{array}$ & \\
\hline \multirow{3}{*}{ UP - IV } & UP - IVa & $\begin{array}{l}\text { Solos associados } \\
\text { a Formação } \\
\text { Guabirotuba. } \\
\text { Cambissolos } \\
\text { Flúvicos e } \\
\text { Háplicos } \\
\end{array}$ & $\begin{array}{l}\text { Pouca } \\
\text { hidrografia, } \\
\text { quatro } \\
\text { nascentes } \\
\text { aterradas. }\end{array}$ & $\begin{array}{l}\text { Floresta } \\
\text { Ombrófila } \\
\text { Mista } \\
\text { Aluvial. }\end{array}$ & $\begin{array}{l}\text { Vegetação privada, com } \\
\text { pequenos grupos de } \\
\text { arbóreas; arborização de } \\
\text { ruas. }\end{array}$ & \multirow{3}{*}{$\begin{array}{l}\text { Principais avenidas e ruas de } \\
\text { ligação com outros bairros; } \\
\text { grandes estruturas edificadas e } \\
\text { pavimentadas; usos poluidores; } \\
\text { fluxo intenso de veículos; } \\
\text { desertos florísticos e déficit de } \\
\text { Espaços Livres de Edificação; } \\
\text { graves conflitos em APPs. }\end{array}$} \\
\hline & $U P-I V b$ & $\begin{array}{l}\text { Em sua maioria } \\
\text { Cambissolos } \\
\text { Háplicos. }\end{array}$ & $\begin{array}{l}\text { Áreas com } \\
\text { pequenos } \\
\text { afluentes do rio } \\
\text { Cascatinha e } \\
\text { terço superior } \\
\text { do mesmo; } \\
\text { Algumas das } \\
\text { nascentes dos } \\
\text { afluentes do rio } \\
\text { Uvu. }\end{array}$ & $\begin{array}{l}\text { Floresta } \\
\text { Ombrófila } \\
\text { Mista } \\
\text { Montana. }\end{array}$ & $\begin{array}{l}\text { Apresenta a vegetação } \\
\text { arbórea preferencialmente } \\
\text { em quintais; arborização de } \\
\text { ruas; Poucas machas de } \\
\text { vegetação maiores. }\end{array}$ & \\
\hline & UP - IVc & $\begin{array}{l}\text { Solos profundos, } \\
\text { em maioria } \\
\text { Latossolos } \\
\text { Brunos. }\end{array}$ & $\begin{array}{l}\text { Apresenta } \\
\text { apenas uma } \\
\text { nascente. }\end{array}$ & $\begin{array}{c}\text { FOM } \\
\text { Montana } \\
\text { intercalada a } \\
\text { áreas de } \\
\text { Campos } \\
\text { (Estepes). }\end{array}$ & $\begin{array}{c}\text { Vegetação arbórea em } \\
\text { quintais. }\end{array}$ & \\
\hline
\end{tabular}

Os quadros de correlação complementam os mapas de UPOs e UPs com a descrição detalhada das unidades e evidenciando os elementos das unidades de paisagens. Sua organização segue a legenda dos mapas, no caso do mapa de UPs (Figura 3) optou-se por separar as informações nos quadros 2.1 e 2.2 em função da diagramação do artigo.

O resultado final apresentou quatro unidades de paisagem principais sendo que a dinâmica regente das paisagens do bairro, na escala trabalhada, é preferencialmente a antrópica. A comparação entre a Qualidade Ambiental e a Hemerobia das UPs (Quadro 2.1) evidencia a importância que a ocupação antrópica tem nas paisagens atuais, e a comparação com as paisagens originais mostram essa evolução cada vez mais determinada pelos aspectos humanos. No entanto, por mais que os processos antrópicos dominem a evolução da paisagem alguns resquícios das unidades de paisagens originais (pretéritas a ocupação intensa) ainda estão 
presentes e foram consideradas como subunidades de paisagem. Destacam-se os solos nas UPs Ic, IIIc e IVc (Quadro 2.2) e as formas de relevo e clinografia como os vales declivosos nas UPs la e Illa, ou as planícies dos rios nas UPs Ila e IVa (quadro 2.1), que por terem uma característica muito singular, ainda aparecem como fatores decisivos na determinação das subunidades. No restante das unidades são os elementos antrópicos os mais presentes e a sua disposição no espaço diferencia os processos físicos, bióticos e mesmo antrópicos da paisagem, portanto regulando-as.

Em relação às homogeneidades encontradas deve ser dada devida atenção para a coluna que transcreve a estrutura da paisagem, pois, nessa coluna é possível encontrar os principais elementos que determinam como as unidades de paisagem se configuram (Quadro 2.2). Essa é a coluna do quadro que reflete mais fortemente a síntese dos elementos, e chama atenção para os aspectos que definem as UPs, diferentemente das outras colunas que por vezes descrevem os principais elementos de cada UP e sub UP ou, ainda, que mostram sínteses parciais, ou mesmo evolução da paisagem como no caso das colunas voltadas para Vegetação e para Fragmentos Florestais (Quadro 2.2).

Deste modo, com as UPs caracterizadas, pode-se elencar propostas para o seu desenvolvimento futuro como uma forma de planejá-las. Neste trabalho, com base nas premissas do Planejamento da Paisagem, discutidas anteriormente, surgem algumas sugestões para cada uma das UPs.

\section{Unidade de Paisagem I}

Esta UP é a que apresenta melhores condições de qualidade ambiental, menor densidade de edificações, grandes áreas não loteadas, além de menores quantidades de problemas de conflitos ambientais e fontes de poluição. Deste modo as propostas tendem a ser voltadas ao fortalecimento dessas condições, bem como o incremento no verde urbano.

As propostas giram em torno de: criação de novas unidades de conservação municipais, programa de Educação Ambiental com a comunidade local, retiradas das edificações concentradas em áreas de APP, dinamização da atividade de lazer e turística voltada à contemplação de áreas verdes, programa de implantação de hortas e bosques frutíferos de uso público em ambiente urbano, proteção das nascentes, limitação de adensamento ao invés de incentivo ao mesmo. 


\section{Unidade de Paisagem II}

A UP II apresenta uma ocupação não muito intensa, contendo grandes áreas de quintais nas residências ou mesmo terrenos sem edificações. Apresenta níveis baixos e intermediários de hemerobia, e não há tantos conflitos de uso como nas UPs III e IV. No entanto, uma tendência clara é a criação de condomínios fechados, fonte de poluição acústica e atmosférica, de déficit de espaços livres, entres outros.

Assim as propostas para essa UP seriam voltadas para o uso e conservação das paisagens que ainda restam, o que envolveria a criação de novos espaços livres de edificação de pequeno porte, em função da ocupação consolidada e o incentivo a esta prática por meio de leis e impostos. Controle de exóticas e desenvolvimento da arborização nas ruas.

Seguindo uma outra linha, que aborda a infraestrutura local, seria interessante que houvesse a melhoria da condição de uso dos espaços livres existentes (iluminação, limpeza, segurança, deslocamento), bem como a fiscalização dos novos condomínios em relação a tecnologias sustentáveis e mesmo a conservação das funções das paisagens.

\section{Unidade de Paisagem III}

O que caracteriza a UP-III é o seu estágio avançado de urbanização, ou seja, adensamento, modificação dos solos intensa, loteamentos e novas edificações cada vez mais próximas umas das outras. Assim o que a define, com base nos trabalhos estudados é justamente uma alta hemerobia comparando as UPs do bairro, e uma qualidade ambiental pior do que as outras duas UPs discutidas (I e II).

Além dos problemas relatados nas outras UPs, essa apresenta uma intensificação dos mesmos e outros problemas específicos como poluição hídrica, poluição visual, intensos conflitos em APP de nascentes e margem de rios, grande impermeabilização dos solos, alto déficit de espaços livres de edificação de uso público ou privado, solos expostos, modificação no relevo e hidrografia, entre outros.

Desta forma algumas propostas que podem se adequar a essa UP seriam: criação de corredores entre bosques e parques próximos utilizando a arborização de calçadas com espécies nativas, programa de despoluição de rios e nascentes que ainda não foram soterrados, melhoria na coleta de esgotos, de lixo e de abastecimento de água, incentivo a utilização de materiais mais permeáveis em calçamentos, educação ambiental para evitar desperdícios e excessos, melhorias no modal de transporte cicloviário visando o deslocamento pelo meio do bairro com menor utilização de veículos movidos a combustão. 


\section{Unidade de Paisagem IV}

Por fim a UP IV, com os piores índices, relativos, de qualidade ambiental e hemerobia encontradas para o bairro, apresenta urbanização complexa com ruas e avenidas de grande fluxo de veículos, edificações adensadas e de diferentes portes e variados usos, do industrial ao residencial.

Regionalmente o bairro de Santa Felicidade apresenta-se como um centro de serviços para a área noroeste do município de Curitiba e mesmo para municípios vizinhos, essa centralidade construída ao longo do tempo se manifesta na paisagem justamente na UP IV. Assim, tem-se a UP mais complicada em relação a propostas de melhorias no que tange a questão ambiental.

Dentre todos os problemas relatados nas outras UPs e que também estão presentes nessa, destacamse as inundações e alagamentos, alto grau de impermeabilização do solo e ainda a presença de desertos florísticos, conflitos entre usos industriais e residenciais, bem como quase todos os problemas relatados nas UPs anteriormente descritas.

As propostas aqui passam pela conscientização, assim, um programa de educação ambiental seria coerente, mesmo esta UP sendo uma área de fluxo de pessoas muito grande. A proposta seguinte levaria em conta a transição com outras UPs, como mostra a figura 3. Como a UP IV apresenta déficit de áreas verdes, mas no seu entorno, em outras UPs eles estão presentes, seria importante um programa incentivando o turismo voltado para parques e bosques, cabe ressaltar que é nessa UP que se localiza um grande polo turístico gastronômico do município. No aspecto político, seria importante um zoneamento que limitasse o crescimento das áreas dessa UP, uma vez que atualmente há um grande adensamento. Assim como na UP III seria papel do setor público incentivar mudanças em prol do ambiente com base na fiscalização do esgotamento, abastecimento, geração e armazenamento de resíduos, construções sustentáveis, redução da atividade industrial até que seja totalmente deslocada para áreas compatíveis.

\section{CONCLUSÃO}

O conceito de Paisagem adotado por Monteiro (2000), bem como o modo operacional compreendido nas discussões de Delpoux (1974) e Maturana e Varela (1995), em torno da busca de homogeneidades, foram esclarecedores e muito uteis na delimitação das UPs e na análise sistêmica de seus elementos constituintes.

O trabalho buscou aglutinar diferentes dados de diferentes bases cartográficas, e em diferentes extensões de arquivo, neste aspecto o tratamento dos dados em ambiente SIG, com a reorganização das tabelas de dados e ajustes de pontos, polígonos, linhas em função do sistema de projeção e das variações de escala, se deu de modo ágil apesar da grande quantidade de dados. Posteriormente aos ajustes a sobreposição 
dos dados auxiliou a delimitação das UPs, sendo que a confirmação do processo demandou intenso trabalho de campo.

O procedimento técnico adotado na pesquisa mostrou-se capaz de unir em uma mesma plataforma os diferentes elementos da paisagem estudada em uma única carta que para a compreensão do significado das UPs, deve-se utilizar o quadro correlativo. No que tange à cartografia de síntese discutida na revisão e aplicada por meio dos procedimentos de trabalho, conclui-se que as cartas, tanto de UPOs como de UPs atingiram o objetivo de mostrar o resultado da síntese dos diversos elementos estudados por meio da cartografia, o que fez com que a particularidade de cada um não sobrepusesse o todo trazendo ao resultado um caráter integrador.

Por fim a proposição de alternativas para o futuro, mesmo que de modo generalizado, mostra que a delimitação de unidades de paisagem é uma forma de ver o todo e percebendo os problemas que o afetam propor soluções voltadas a manutenção das funções da paisagem, da qualidade ambiental e para uma redução na dependência tecnológica que as paisagens antropizadas acabam reproduzindo.

\section{REFERÊNCIAS}

ABRAHÃO, C. M. DE S. Síntese e complexidade no pensamento Geográfico. Sociedade e Natureza. Uberlândia, n. 2, p. 211-225, 2009.

ALEMANHA. Federal Nature Conservation Act (tradução). n. L, p. 1-127, 2002.

BELEM, A. L. G.; NUCCI, J. C. Classificação dos espaços livres de edificação de acordo com o tipo de uso no bairro de Santa Felicidade (Curitiba-PR). In: NUCCI, J. C. Planejamento da Paisagem como subsídio para a participação popular no desenvolvimento urbano Estudo aplicado ao bairro de Santa Felicidade - Curitiba/PR. Curitiba: o autor, 2010, p. 277. p.143-157.

BELEM, A. L. G. Unidades de Paisagem do bairro Santa Felicidade, Curitiba PR: Propostas ao planejamento e ordenamento da paisagem. 2013. 86f. Dissertação (Mestrado em Geografia) - Setor de Ciências da Terra, Universidade Federal do Paraná, Curitiba, 2013.

BERTRAND, G. Paisagem e geografia física global. Esboço metodológico. RA'E GA - O Espaco Geografico em Analise. Curitiba. n. 8, p. 141-152, 2004.

CAPRA, F. As conexões ocultas: ciência para uma vida sustentável. São Paulo: Cultrix, 2002. 296p.

CAVALCANTI, L. C de S. Cartografia de paisagens, fundamentos. São Paulo: Oficina de textos, 2014. 96p.

COMEC. Levantamento Topográfico. Curitiba, 1987. 1 CD-ROM.

DELPOUX, M. Ecossistema e Paisagem. Métodos em Questão. São Paulo.n.13.p.1-23, 1974.

FERREIRA, V. D. O. A abordagem da paisagem no âmbito dos estudos ambientais integrados. Revista Geotextos. Salvador. n. 2, p. 187-208, 2010.

HAAREN, C. VON; GALLER, C.; OTT, S. Landscape planning: the basis of sustainable landscape development. 2008. 52p. 
HARDING, S. Terra viva. Ciência, intuição e a evolução de Gaia. Para uma nova compreensão do nosso planeta. São Paulo: Cultrix, 2008. 312p.

INSTITUTO BRASILEIRO DE GEOGRAFIA E ESTATÍSTICA. Manual técnico da vegetação brasileira. Rio de Janeiro, 1992, 91p. INSTITUTO DE PESQUISA E PLANEJAMENTO URBANO DE CURITIBA. Curitiba em dados. Disponível em www.ippuc.org.br. Acesso em: 12 de abril de 2012.

KLEIN, R. M.; HATSCHBACH, G. Fitofisionomia e notas sobre a vegetação para acompanhar a Planta Fitogeográfica do município de Curitiba e arredores. Boletim da Universidade do Paraná. Curitiba. p.1-30. 1962.

KIEMSTEDT, H.; von HAAREN, C.; MÖNNECKE, M.; OTT, S. Landscape Planning. Contents and Procedures. Bonn: Federal Ministry for the Environment, Nature Conservation and Nuclear Safety, 1998, 39p.

KRÖKER, R. Transformação da paisagem e estado hemerobiótico do bairro Santa Felicidade.2008. 111 f. Dissertação (Mestrado em Geografia) - Setor de Ciências da Terra, Universidade Federal do Paraná, Curitiba, 2008.

LEVANTAMENTO DE SOLOS DO BRASIL. Brasília: EMBRAPA, 2008.

MAACK, R. Geografia Física do Estado do Paraná. Curitiba: imprensa oficial, 2002. 526p.

MARTINELLI, M. Mapas da Geografia e Cartografia Temática. São Paulo: Contexto, 2006. 112p.

MATURANA, H.; VARELA, F. A árvore do conhecimento: As bases biológicas do entendimento humano. Campinas: Editorial Psy II, 1995. 130p.

MCHARG, I. Design with nature. New York: Back Edition, 1971, 198p.

MEZZOMO, M. M.; NÓBREGA, M. T. DE. Paisagem na perspectiva integrada: alguns apontamentos. Perspectiva Geográfica. Marechal Cândido Rondon. n.4 p. 153-168, 2008.

MONTEIRO, C.A. de F. Qualidade Ambiental - Recôncavo e Regiões Limítrofes. Salvador, Centro de Estatística e Informações, 1987, 48p. e 3 cartas.

MONTEIRO, C. A. DE F. Geossistema a história de uma procura. São Paulo: Contexto, 2000. 127p.

MOURA, A. R. de; NUCCI, J. C. Conservação em áreas de preservação permanente no bairro de Santa Felicidade, Curitiba/PR. In: SIMPÓSIO BRASILEIRO DE GEOGRAFIA FÍSICA APLICADA, XII., 2007, Natal. Anais... Natal: UFRN, 2007, p. 1-15.

MOURA, A. R. de; NUCCl, J. C. Cobertura vegetal em áreas urbanas - o caso do bairro Santa Felicidade Curitiba/PR. Geografia. Ensino \& Pesquisa, Santa Maria. p. 1682-1698, 2008.

NAVEH, Z.; LIEBERMAN, A.S. Landscape Ecology. Theory and Application. New York: Springer-Verlag, 1984, 105p.

NAVES, J G de P.; BERNARDES, M. B. J. A relação histórica homem/natureza e sua importância no enfrentamento da questão ambiental. Geosul. Florianópolis. n.57. p.7-27 2014.

NUCCI, J. C. Qualidade ambiental e adensamento: um estudo de planejamento da paisagem do distrito de Santa Cecília. Tese (Doutorado em Geografia) - Faculdade de Filosofia, Letras e Ciências Humanas, Universidade de São Paulo, São Paulo, 1996.

NUCCI, J.C. Origem e desenvolvimento da Ecologia e da Ecologia da Paisagem. Geografar. Curitiba. n. 1, p.77-99. 2007.

NUCCI, J. C. Qualidade Ambiental e Adensamento Urbano. Curitiba: o autor, 2008.150p.

NUCCl, J. C. Planejamento da Paisagem como subsídio para a participação popular no desenvolvimento urbano . Estudo aplicado ao bairro de Santa Felicidade - Curitiba / PR. Curitiba: o autor, 2010.277p.

PUEBLA, A. M. R.; SALINAS-CHAVEZ, E.; NOA, R. R. Diseño metodológico para la elaboración de mapas de paisaje con el uso de los SIG: aplicación a la cuenca alta del Río Cauto, Cuba. Revista digital del grupo de estudios sobre geografía y análisis espacial con SIG. Lújan. n. 1, p. 95-108, 2009. 
PUGLIELLI NETO, H. F. Análise da fragmentação da cobertura vegetal como subsídio ao planejamento da paisagem em áreas urbanizadas: aplicação ao bairro de Santa Felicidade, Curitiba/PR. 2008. 174f. Dissertação (Mestrado em Geografia) - Setor de Ciências da Terra, Universidade Federal do Paraná, Curitiba, 2008.

RODERJAN, C. V.; GALVÃO, F.; KUNIYOSHI, Y. S.; HATSCHBACH, G. G. As unidades fitogeográficas do estado do Paraná. Ciência \& Ambiente. Santa Maria. n. 24, p. 75-92.2002.

SANTOS, J. H. dos Na esteira da abordagem sistêmica. In: SANTOS, J. M. dos; FARIA, M. Reflexões e construções geográficas contemporâneas. Salvador: os autores. 2004.

SCHMIDT, E. Avaliação da qualidade ambiental urbana do bairro Santa Felicidade, Curitiba/PR. 2009. 115f. Dissertação (Mestrado em Geografia) - Setor de Ciências da Terra, Universidade Federal do Paraná, Curitiba, 2009.

SOTCHAVA, V. O estudo de geossistemas. Métodos em Questão. São Paulo. p. 1-49. 1977.

SUERTEGARAY, D. M. A.; NUNES, J. O. R. A natureza da Geografia Física na Geografia. Terra Livre. São Paulo. n.17. p.11-24. 2001.

TOLEDO, V. M. Contra nós mesmos? A consciência da espécie e o surgimento de uma nova filosofia científica. In: MONJEAU, A. ECOFILOSOFIA. Curitiba: Fundação O Boticário de Proteção à Natureza, 2008. 425p.

TOMASONI, M. A. Considerações sobre a abordagem da natureza em geografia. In: SANTOS, J. M. dos; FARIA, M. Reflexões e construções geográficas contemporâneas. Salvador: Organizadores, 2004.

VALASKI, S. Avaliação da qualidade ambiental em condomínios residenciais horizontais com base nos princípios do planejamento da paisagem estudo de caso: bairro Santa Felicidade - Curitiba/PR. 2008.152f. Dissertação (Mestrado em Geografia) - Setor de Ciências da Terra, Universidade Federal do Paraná, Curitiba, 2008.

VITTE, A. C. O desenvolvimento do conceito de paisagem e sua inserção na geografia física. Mercator, v. 3, p. 71-78, 2007.

WILKE, T.; SCHILLER, J.; KÖNZE, M. Landscape planning the Federal Agency for sustainable municipal development. Leipizig: German Federal Agency for Nature Conservation, 2002.

ZACHARIAS, A. A. et al. A cartografia de Síntese no planejamento e gestão ambiental. In: Simpósio de Geografia Física Aplicada. 13. 2009. Anais...Viçosa: 2009. CD ROM.

ZONNEVELD, I.S.; FORMAN, R.T.T. Changing Landscape: an ecological perspective. New York: Springer-Verlag, 1990, 286p. 